\title{
Particle size alterations of feedstuffs during in situ neutral detergent fiber incubation
}

\author{
M. Krämer, ${ }^{* 1}$ P. Nørgaard,† P. Lund, ${ }^{*}$ and M. R. Weisbjerg* \\ *Department of Animal Science, Aarhus University, AU Foulum, Blichers Allé 20, PO BOX 50, DK-8830 Tjele, Denmark \\ †Department of Veterinary Clinical and Animal Sciences, Faculty of Health and Medical Sciences, Copenhagen University, \\ DK-1165 Copenhagen K, Denmark
}

\begin{abstract}
Particle size alterations during neutral detergent fiber (NDF) determination and in situ rumen incubation were analyzed by dry sieving and image analysis to evaluate the in situ procedure for estimation of NDF degradation parameters and indigestible NDF concentration in terms of particle size. Early-cut and late-cut grass silages, corn silage, alfalfa silage, rapeseed meal, and dried distillers grains were examined. Treatments were (1) drying and grinding of forage samples and grinding of concentrates; (2) neutral detergent-soluble (NDS) extraction; (3) machine washing and NDS extraction; (4) 24-h rumen incubation, machine washing, and NDS extraction; and (5) 288-h rumen incubation, machine washing, and NDS extraction. Degradation profiles for potentially degradable NDF were determined and image analysis was used to estimate particle size profiles and thereby the risk for particle loss. Particle dimensions changed during NDF determination and in situ rumen incubation and variations depended on feedstuff and treatment. Corn silage and late-cut grass silage varied most in particle area among feedstuffs, with an increase of $139 \%$ between 0 and $24 \mathrm{~h}$ and a decrease of $77 \%$ between 24 and $288 \mathrm{~h}$ for corn silage and a decrease of $74 \%$ for late-cut grass silage between 24- and 288-h in situ rumen incubation. Especially for late-cut grass silage residues after $288 \mathrm{~h}$ in situ rumen incubation, a high mass proportion in the critical zone for escape was found. Particle area decreased linearly with increasing incubation time. Particle loss during in situ rumen incubation cannot be excluded and is likely to vary among feedstuffs.
\end{abstract}

Key words: Dacron bag, rumen, method, image analysis

Received February 1, 2013.

Accepted March 27, 2013.

${ }^{1}$ Corresponding author: Monika.Kramer@agrsci.dk

\section{INTRODUCTION}

Fiber is a major energy source in ruminant feedstuffs. Fiber digestion and passage behavior have a great influence on the net energy value of a ration, as cell contents are almost completely digestible. Chemically, fiber can be defined as the residue after boiling feedstuffs in neutral detergent (ND) solution and is indicated as NDF (Van Soest and Wine, 1967; Mertens et al., 2002). Potential digestibility and degradation rate of potentially digestible NDF (pdNDF) determine the availability of NDF in the rumen and thereby the energy availability for the ruminant (Huhtanen et al., 2006). Indigestible NDF (iNDF) is an important input factor in new feed evaluation systems (NRC, 2001; Volden, 2011) and can be determined by in situ rumen incubation of feedstuffs in Dacron bags, followed by machine washing and analysis of the residual NDF. Reliability of results from in situ rumen incubation, however, depends on the complete retention of iNDF in the Dacron bags. Grinding of feedstuffs before in situ incubation might produce small particles that can be lost from the Dacron bags due to their dimensions. Immediate particle loss of small particles can be taken into account when estimating NDF degradation rate through correction for particles lost from bags during machine washing (Åkerlind et al., 2011). Particle loss during rumen incubation is not accounted for in the in situ approach. Akin (1993) suggested that chewing mainly reduces particles in size, whereas degradation by rumen microorganisms was not expected to affect particle size. Microbial degradation, however, was shown to weaken plant structures (Akin, 1993), which subsequently could be mechanically broken during rumen contractions and, therefore, reduced in particle size. Differences among feedstuffs in particle dimension alterations during rumen incubation and thereby potential particle loss could be due to intrinsic plant characteristics such as plant origin and maturity (Akin, 1989; Wilson and Kennedy, 1996).

The hypothesis was that mean particle length, width, and area remain constant during rumen incubation. Particle loss from Dacron bags was, therefore, not expected during in situ rumen incubation. The objective 
was to describe changes in particle dimensions during NDF determination and in situ rumen incubation.

\section{MATERIALS AND METHODS}

\section{Feedstuffs}

Forage and concentrate feedstuffs were investigated. Forages were corn silage, early- and late-cut grass silage, and alfalfa silage. Corn silage was harvested on October 26, 2010. Early-harvested, primary growth grass silage was cut on May 26, 2010. Late-harvested, primary growth grass silage was cut on June 15, 2010. Both grass silages contained less than $10 \%$ clover. Regrowth alfalfa silage was cut on June 24, 2009. Grass and alfalfa were prewilted before ensiling.

Concentrates were rapeseed meal and dried distillers grains (DDG). Dried distillers grains consisted of $80 \%$ wheat, $10 \%$ triticale, and $10 \%$ rye on a DM basis and were delivered by Lantmännen Agroetanol $\mathrm{AB}$ (Norrköping, Sweden). Rapeseed meal was delivered by DLG (Viborg, Denmark).

Forages were dried for $48 \mathrm{~h}$ at $60^{\circ} \mathrm{C}$ in a forced-air drying cabinet. All dried forages and concentrates were ground through a $1.5-\mathrm{mm}$ screen using a cutter mill (Pulverisette 15; Fritsch GmbH, Idar-Oberstein, Germany). The nutrient composition of the feedstuffs is given in Table 1.

\section{Degradation of Fiber}

Degradation in the present study is the term used for disappearance of particles from Dacron bags. Dried and ground feed samples ( $2 \mathrm{~g}$ each) were incubated in Dacron bags. Bags were incubated for 0, 24, 48, 96, and $288 \mathrm{~h}$ in the rumen of 3 nonlactating cows. Zero-hour bags were only presoaked and machine washed. The NDF degradation profile and iNDF determination for each feedstuff were determined using Dacron bags with both 12- $\mu \mathrm{m}$ (Saatifil PES 12/6, $10.5 \times 8 \mathrm{~cm}^{2}$ in size, $0.06 \mathrm{~mm}^{2} / \mathrm{mm}^{2}$ open surface area; SaatiTech S.p.A., Como, Italy) and $38-\mu \mathrm{m}$ pore size (Saatifil PES 38/31, $9 \times 7.5 \mathrm{~cm}^{2}$ in size, $0.31 \mathrm{~mm}^{2} / \mathrm{mm}^{2}$ open surface area;
SaatiTech S.p.A.). All in situ incubations followed the protocol of Åkerlind et al. (2011).

A maximum of 6 bags were mounted on 1 rubber stopper using a cable tie. Bags incubated for NDF degradation profile were mounted on rubber stoppers equipped with hooks and fixed on a plastic tube. At each end, plastic tubes were equipped with a weight of $200 \mathrm{~g}$ and a $40-\mathrm{cm}$ string fixed to a plastic ring placed outside the rumen cannula to maintain bags in the rumen mat and to allow movement with rumen contractions. Bags were presoaked for 20 min in $39^{\circ} \mathrm{C}$ warm tap water without agitation before rumen incubation. For 288-h rumen incubation (iNDF determination), a maximum of 9 rubber stoppers were gathered in a household washing net with 2 weights, each of $912 \mathrm{~g}$. A maximum of 16 rubber stoppers were incubated in the ventral rumen of each cow. The weights in the washing net were used to maintain rubber stoppers in the ventral rumen during the whole incubation period.

All bags were incubated at the same time of the day $(0800 \mathrm{~h})$ before the morning feeding and retrieved according to their respective incubation times. After rumen incubation, bags on the rubber stopper were rinsed with cold tap water and machine washed (AEG, Fredericia, Denmark) twice for 5 min with $22 \mathrm{~L}$ of water at $25^{\circ} \mathrm{C}$. Subsequently, bags were frozen at $-20^{\circ} \mathrm{C}$ until analysis.

Three nonlactating Danish Holstein cows were used for rumen incubations. Cows were fed at maintenance level with a diet consisting of $2 \mathrm{~kg}$ of artificially dried grass-clover hay, $4 \mathrm{~kg}$ of barley straw, and $2.8 \mathrm{~kg}$ of pelleted concentrate mixture as fed. The daily feed allowance was distributed between 2 meals of equal size. The concentrate consisted of $40 \mathrm{~kg}$ of barley grain, 40 $\mathrm{kg}$ of oat grain, $10 \mathrm{~kg}$ of soybean meal, $3 \mathrm{~kg}$ of rapeseed meal, $3 \mathrm{~kg}$ of sugar beet molasses, and $4 \mathrm{~kg}$ of a commercial mineral mixture $(6 \mathrm{~g}$ of $\mathrm{Ca} / 100 \mathrm{~g}, 10 \mathrm{~g}$ of $\mathrm{P} / 100 \mathrm{~g}, 12 \mathrm{~g}$ of $\mathrm{Mg} / 100 \mathrm{~g}$, and $5 \mathrm{~g}$ of Na/100 g; Type 3; Vitfoss A/S, Gråsten, Denmark) per $100 \mathrm{~kg}$ of fresh mixture. The forage-to-concentrate ratio in the ration was $670: 330$ on a DM basis and the $\mathrm{CP}$ concentration was $139 \mathrm{~g} / \mathrm{kg}$ of DM.

Table 1. Nutrient composition of the feedstuffs

\begin{tabular}{|c|c|c|c|c|c|c|}
\hline \multirow{2}{*}{$\begin{array}{l}\text { Nutrient, } \\
\mathrm{g} / \mathrm{kg} \text { of DM }\end{array}$} & \multicolumn{2}{|c|}{ Grass silage } & \multirow{2}{*}{$\begin{array}{c}\text { Corn } \\
\text { silage }\end{array}$} & \multirow{2}{*}{$\begin{array}{l}\text { Alfalfa } \\
\text { silage }\end{array}$} & \multirow[b]{2}{*}{$\mathrm{DDG}^{1}$} & \multirow{2}{*}{$\begin{array}{c}\text { Rapeseed } \\
\text { meal }\end{array}$} \\
\hline & Early cut & Late cut & & & & \\
\hline Ash & 94.0 & 81.5 & 35.9 & 116 & 47.7 & 76.0 \\
\hline $\mathrm{CP}$ & 177 & 128 & 82.2 & 216 & 338 & 383 \\
\hline NDF & 380 & 496 & 479 & 324 & 223 & 251 \\
\hline $\mathrm{ADF}$ & 251 & 330 & 298 & 305 & 148 & 210 \\
\hline ADL & 16.3 & 28.0 & 30.6 & 58.7 & 46.7 & 93.3 \\
\hline ADL:NDF ratio & 0.043 & 0.056 & 0.064 & 0.181 & 0.209 & 0.372 \\
\hline
\end{tabular}

${ }^{1}$ Dried distillers grains. 


\section{Particle Size in Feedstuffs}

Dry Sieving. Five sets of samples were prepared for dry sieving, including (1) dried and ground forage samples and ground concentrates (FD); (2) treatment FD, followed by ND-soluble (NDS) extraction to obtain NDF feed residues (FBR); (3) treatment FD, followed by machine washing and NDS extraction (I00); (4) treatment FD, followed by 24-h rumen incubation, machine washing, and NDS extraction (I24); and (5) treatment FD, followed by 288-h rumen incubation, machine washing, and NDS extraction (I288). Animals, feeding, and the incubation procedure were as described for degradation of fiber.

Rumen incubation (I00, I24, and I288) and treatment of nonincubated samples (FD and FBR) followed the procedures of Åkerlind et al. (2011), except that feed samples of $4 \mathrm{~g}$ were incubated in Dacron bags with $12-\mu \mathrm{m}$ pore size. Bags, sample preparation, and rumen incubations followed the procedure described for 288-h samples in the Degradation of Fiber section. The number of bags for each feedstuff and treatment were based on assumptions about NDF degradation characteristics and washing losses and varied from 6 to 39 to obtain sufficient residues. Bag residues after incubation were quantitatively transferred to larger $12-\mu \mathrm{m}$ Dacron bags to pool them within feedstuff and cow and dried at $60^{\circ} \mathrm{C}$ for $48 \mathrm{~h}$ in a forced-air drying cabinet. Ten grams of dry sample material from treatments FBR and I00, $7 \mathrm{~g}$ from treatment I24, and $4 \mathrm{~g}$ from treatment I288 was transferred to $12-\mu \mathrm{m}$ Dacron bags $\left(10.5 \times 8 \mathrm{~cm}^{2}\right.$ in size). To extract the nonfiber fraction of feedstuffs, bags were soaked for $30 \mathrm{~min}$ in ND. Bags were transferred to a 10-L household pot and a minimum of $50 \mathrm{~mL}$ of ND, $0.5 \mathrm{~g}$ of anhydrous $\mathrm{Na}_{2} \mathrm{SO}_{3}$ (Merck KGaA, Darmstadt, Germany), and $0.1 \mathrm{~mL}$ of heat-stable $\alpha$-amylase (activity: 17,400 liquefon U/mL; Ankom Technology, Macedon NY) per $1 \mathrm{~g}$ of sample material were added and boiled for $1 \mathrm{~h}$. Bags were washed 3 times; each wash used $50 \mathrm{~mL}$ of boiling demineralized water and lasted 4 $\min (0.1 \mathrm{~mL}$ of heat-stable $\alpha$-amylase added in the first wash per $1 \mathrm{~g}$ of sample material) to ensure complete removal of NDS extract. Bags were squeezed after each washing and subsequently transferred to a bottle with $5 \mathrm{~mL}$ of acetone (VWR International BVBA, Haasrode, Belgium) per $1 \mathrm{~g}$ of sample and hand shaken for $1 \mathrm{~min}$. Bags were allowed to soak in acetone for an additional 3 min. Bags were squeezed, placed in a fume cupboard for $30 \mathrm{~min}$, freeze dried to avoid clumping, and subsequently dried at $60^{\circ} \mathrm{C}$ for $12 \mathrm{~h}$ in a forced-air drying cabinet.

Samples were dry sieved with a vertical sieve shaker (Retsch AS 200; Retsch GmbH, Haan, Germany). Four sieves with square holes of $1,0.5,0.212$, and $0.106 \mathrm{~mm}$ and a bottom bowl (Nørgaard et al., 2004) were used. Sieving time was 3 min and sieving quality was visually assessed and if not satisfactory, particles were separated manually with a custom painting brush. Particles were removed with a brush and forceps starting with the top sieve. Particles retained on each sieve fraction were weighed to calculate the mass proportion of particulate matter retained on the single sieves.

Image Analysis. Two subsamples from the 1- (10$\mathrm{mg}$ ), 0.5- (5-mg), and 0.212-mm (1-mg) sieves were placed with forceps on a HP Scanjet 8300 Scanner (Hewlett-Packard, Allerød, Denmark) surface and multicolor scanned against a blue background at 2,400 dots per inch as in Nørgaard et al. (2004). One subsample from the $0.106-\mathrm{mm}$ sieve and 1 from the bottom bowl, each of about $1 \mathrm{mg}$, were placed on a ScanMate F8 Plus scanner (Purup Eskofot, Brøndby, Denmark) and surface and color scanned against a blue background at 4,800 dots per inch. Overlapping particles were manually separated using forceps before scanning. Background segmentation was performed, individual particles identified, and individual particle length $\left(\mathbf{P L}_{\mathbf{i}}\right)$, width $\left(\mathbf{P} \mathbf{W}_{\mathbf{i}}\right)$, and area $\left(\mathbf{P A}_{\mathbf{i}}\right)$ measured using Image-Pro Plus software (version 5.5, 2007; Media Cybernetics Inc., Rockville, MD). Individual PL and PW were defined as the length and the width of the smallest rectangle surrounding the whole particle. Individual PA is the exact area covered by the particle. Particle area smaller than $144 \times 10^{-6} \mathrm{~mm}^{2}$ corresponds to the $12-\mu \mathrm{m}$ Dacron bag pore size area and was used to estimate particle mass proportion that did not escape from $12-\mu \mathrm{m}$ Dacron bags. Particle mass proportion with an area smaller than $0.005 \mathrm{~mm}^{2}$ was used to estimate the particle mass proportion, which potentially can escape from Dacron bags with $38-\mu \mathrm{m}$ pore size $\left(0.0014 \mathrm{~mm}^{2}\right)$.

\section{Chemical Analysis}

Dry matter content of the samples was determined after drying in a forced-air drying cabinet at $60^{\circ} \mathrm{C}$ for $48 \mathrm{~h}$. Samples for chemical analysis were freeze dried and ground through a 1-mm screen in a hammer mill. Ash was determined after combustion at $525^{\circ} \mathrm{C}$ for 6 h. Acid detergent lignin and ADF were determined according to International Organization for Standardization method 13908 (ISO, 2008). Acid detergent lignin, $\mathrm{ADF}$, and ash-free NDF were analyzed in a Fibertec 2010 system (Foss Electric A/S, Hillerød, Denmark). Neutral detergent fiber analysis included amylase treatment and was done according to Mertens et al. (2002). Nitrogen was analyzed by the Dumas method (Hansen, 1989) using a vario MAX CN elemental analyzer (Elementar Analysensysteme GmbH, Hanau, Germany). 


\section{Calculations}

Particle Size Dimensions. Arithmetic mean particle size within feedstuff and treatment after dry sieving was calculated using the following equation:

arithmetic mean particle size $=$

$$
\begin{aligned}
& (\mathrm{B} \times 0.05)+[\mathrm{C} \times \sqrt{(0.106 \times 0.212)}]+[\mathrm{D} \times \sqrt{(0.212 \times 0.5)}] \\
& +[\mathrm{S} \times \sqrt{(0.5 \times 1)}]+[\mathrm{M} \times \sqrt{(1 \times 2.36)}],
\end{aligned}
$$

where $\mathrm{B}=$ mass proportion of particles $<0.106 \mathrm{~mm}$, $\mathrm{C}=$ mass proportion of particles retained on the sieve with $0.106-\mathrm{mm}$ screen size, D = mass proportion of particles retained on the sieve with $0.212-\mathrm{mm}$ screen size, $\mathrm{S}=$ mass proportion of particles retained on the sieve with $0.5-\mathrm{mm}$ screen size, and $\mathrm{M}=$ mass proportion of particles retained on the sieve with 1-mm screen size.

Arithmetic mean PL (APL) within each sieve fraction $(\mathrm{j})$ was calculated using the following equation: $\mathrm{APL}_{\mathrm{j}}=\left[\sum\left(\mathrm{PL}_{\mathrm{ij}} \times \mathrm{PA}_{\mathrm{ij}}\right)\right] / \sum \mathrm{PA}_{\mathrm{ij}}$ according to Nørgaard (2006). The variance of PL within each sieve fraction was calculated as $\left[\sum\left(\mathrm{PL}_{\mathrm{ij}} \times \mathrm{PL}_{\mathrm{ij}} \times \mathrm{PA}_{\mathrm{ij}}\right)\right] / \sum \mathrm{PA}_{\mathrm{ij}}-\mathrm{APL}_{\mathrm{j}}^{2}$. Arithmetic mean and variance for $\mathrm{PW}$ and $\mathrm{PA}$ values were estimated accordingly. A gamma distribution function was estimated for PL, PW, and PA within each sieve fraction from arithmetic mean and variance values. Overall probability density functions were estimated for PL, PW, and PA as the composite function after weighting the gamma distribution function with the particle mass proportion of each sieve fraction (derived from dry sieving). Arithmetic mean overall values were calculated by weighting the arithmetic mean values in each sieve fraction with the particle mass proportion of the respective sieve fraction (Nørgaard, 2006). Particle length, PW, and PA values are arithmetic mean overall values, if not otherwise indicated.

Overall cumulative density functions (CDF) were estimated for PL, PW, and PA as composite functions after weighting CDF for each sieve fraction, with the mass proportion within each sieve fraction as described in Nørgaard (2006), using the CDF distribution function in SAS version 9.2 (SAS Institute, 2000). The proportion of particle mass smaller than $144 \times 10^{-6}$ $\mathrm{mm}^{2}$ and smaller than $0.005 \mathrm{~mm}^{2}$ was estimated from the CDF function for PA.

NDF Degradation Profile. Potentially degradable NDF was calculated as the NDF degradability after 288-h rumen incubation. Degradabilities of NDF for the respective incubation times were fitted separately for $12-\mu \mathrm{m}$ bags and $38-\mu \mathrm{m}$ bags to the following equation: NDF degraded $(\mathrm{t})=\mathrm{a}+\mathrm{b} \times\left(1-\mathrm{e}^{-\mathrm{ct}}\right)$, where $\mathrm{t}=$ incubation time, $\mathrm{a}=$ estimated NDF particle loss during machine washing, $b=$ potentially degradable NDF not lost during machine washing, and $\mathrm{c}=$ degradation rate of b using PROC NLIN in SAS (SAS Institute, 2000). All parameters were estimated for each of the 3 cows and then averaged.

\section{Statistical Analysis}

Statistical analyses were performed using the $\mathrm{R}$ program, version 2.14.0 (Crawley, 2007). Potentially digestible NDF, $a, b$, and $c$ were analyzed by a general linear model including the fixed effects of feedstuff and bag pore size.

Relative mass proportion of particles retained on each sieve, mean particle size after dry sieving, PL, PW, PA, and mass proportion of particles with an area smaller than $144 \times 10^{-6} \mathrm{~mm}^{2}$ and smaller than 0.005 $\mathrm{mm}^{2}$ were analyzed by a general linear model including fixed effects of feedstuff and treatment. Response variables were analyzed either including all 5 treatments or including only incubated samples (I00, I24, or I288). When only incubated samples were included, treatment was either included as fixed effect or as continuous variable to test for linear treatment effects. For image analysis data (PL, PW, and PA), differences between treatments FD and FBR and differences between I00 and I288 were tested with orthogonal contrasts after grouping feedstuffs into forages and concentrates.

\section{RESULTS}

\section{Degradation of Fiber}

Neutral detergent fiber lost during machine washing (loss; Table 2) and estimated washing losses (a; Table 2 ) differed between feedstuffs $(P=0.009$ for loss and $P=0.004$ for a), with the highest values for rapeseed meal in $38-\mu \mathrm{m}$ Dacron bags [92 g of NDF $/ \mathrm{kg}$ (for both loss and a)] and alfalfa silage in 12- $\mu \mathrm{m}$ Dacron bags [75 $\mathrm{g}$ of NDF $/ \mathrm{kg}$ (loss) and $67 \mathrm{~g}$ of NDF/kg (a)]. Neutral detergent fiber lost during machine washing tended to increase with increased pore size $(P=0.084$ for loss and $P=0.047$ for a). Measured pdNDF (after 288$\mathrm{h}$ rumen incubation) differed between feedstuffs ( $P$ $<0.001$ ), with the highest values for early-cut grass silage (93 g of NDF/ $\mathrm{kg}$ in 12- and 38- $\mu \mathrm{m}$ Dacron bags) and the lowest for rapeseed meal (56 g of NDF $/ \mathrm{kg}$ in 12 - and $38-\mu \mathrm{m}$ Dacron bags). Potentially degradable NDF not lost during machine washing (b; Table 2) was higher for 12 - than for $38-\mu \mathrm{m}$ Dacron bags $(P=0.010)$, and differed between feedstuffs $(P<0.001)$, with the highest values for early-cut grass silage (93 $\mathrm{g}$ of NDF/ $\mathrm{kg}$ in $12-\mu \mathrm{m}$ and $92 \mathrm{~g}$ of $\mathrm{NDF} / \mathrm{kg}$ in $38-\mu \mathrm{m}$ Dacron 
Table 2. Degradation characteristics of NDF fractions for forage and concentrate feedstuffs after incubation in Dacron bags with $12-\mu \mathrm{m}$ and $38-\mu \mathrm{m}$ pore size

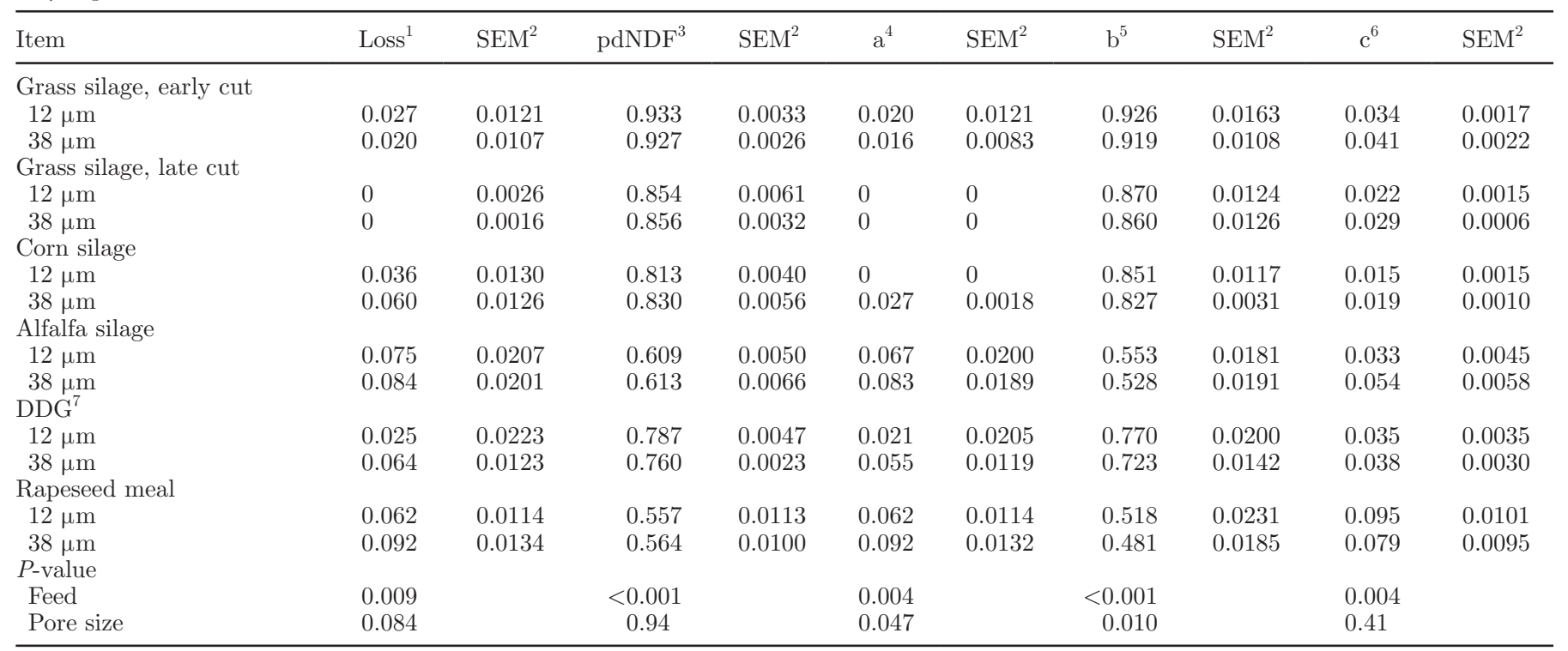

${ }^{1}$ Neutral detergent fiber lost during machine washing (proportion of NDF).

${ }^{2} \mathrm{n}=3$, corresponding to 3 cows.

${ }^{3}$ Potentially degradable NDF (degraded after 288-h rumen incubation; proportion of NDF).

${ }^{4} \mathrm{a}=$ estimated particle loss during machine washing (proportion of NDF).

${ }^{5} \mathrm{~b}=$ potentially degradable NDF not lost during machine washing (proportion of NDF).

${ }^{6} \mathrm{c}=$ degradation rate of $\mathrm{b}\left(\mathrm{h}^{-1}\right)$.

${ }^{7}$ Dried distillers grains.

bags) and lowest for rapeseed meal (52 $\mathrm{g}$ of $\mathrm{NDF} / \mathrm{kg}$ in $12-\mu \mathrm{m}$ and $48 \mathrm{~g}$ of $\mathrm{NDF} / \mathrm{kg}$ in $38-\mu \mathrm{m}$ Dacron bags; Table 2). Degradation rate of b (c; Table 2) was highest for rapeseed meal $\left(0.095 \mathrm{~h}^{-1}\right.$ in $12-\mu \mathrm{m}$ and $0.079 \mathrm{~h}^{-1}$ in $38-\mu \mathrm{m}$ Dacron bags) and lowest for corn silage (0.015 $\mathrm{h}^{-1}$ in $12-\mu \mathrm{m}$ and $0.019 \mathrm{~h}^{-1}$ in $38-\mu \mathrm{m}$ Dacron bags; $P$ $=0.004)$.

\section{Particle Size in Feedstuffs}

Dry Sieving and Image Analysis. Treatment did not systematically affect particle mass proportion in the sieve fractions and mean particle size (Table 3). Feedstuff affected mass proportion of particles retained on the sieve with 0.5 -mm screen size $(P=0.017)$ and tended to influence particle mass proportions retained on the other sieves, except for the sieve with $0.212-\mathrm{mm}$ screen size when all treatments were included. When only incubated samples were considered (I00, I24, and I288) with fixed treatment effects, feedstuff affected the mass proportion of particles retained on sieves with screen size equal or larger than $0.212 \mathrm{~mm}$, tended to affect particle mass proportion in the bottom bowl $(P$ $=0.087)$, and affected mean particle size $(P=0.002)$. When mean particle sizes among treatments within feedstuffs were compared, the highest mean particle size was found for treatment I00 for early-cut grass silage $(0.69 \mathrm{~mm})$ and for late-cut grass silage $(0.71 \mathrm{~mm})$. For corn silage, the highest mean particle size was found for treatment I24 $(0.56 \mathrm{~mm})$ and for alfalfa silage, the highest mean particle size was found for treatment FBR $(0.64 \mathrm{~mm})$. For DDG $(0.70 \mathrm{~mm})$ and for rapeseed meal $(0.55 \mathrm{~mm})$, the highest mean particle size was shown for treatment FD. The highest particle mass proportion was retained on sieves with screen size 0.212 and 0.5 $\mathrm{mm}$. The highest mass proportion of particles in the bottom bowl $(<0.106 \mathrm{~mm})$ among incubated samples (treatments I00, I24, and I288), were for early- (5.5\%) and late-cut (7.6\%) grass silage after treatment I288; for corn silage $(8.3 \%)$ after treatment I00; and for alfalfa silage (3.6\%), DDG (14.5\%), and rapeseed meal $(5.7 \%)$ after treatment I24 (Table 3 ).

No general trend in the particle dimension alterations for all feedstuffs was found when 2 treatments were compared as follows: FD and FBR, FBR and I00, I00 and I24, and I24 and I288. Particle length, PW, and PA had the same range within forage samples and within concentrate samples (Table 4).

Particle Length. Particle length differed among feedstuffs, with the highest values for early-cut grass silage $(3.16 \pm 0.72 \mathrm{~mm}$; mean $\pm \mathrm{SD})$ and lowest for DDG $(0.94 \pm 0.16 \mathrm{~mm})$ when all treatments were in- 
Table 3. Mass proportion of forage and concentrate particles $(\%)$ in the bottom bowl $(<0.106 \mathrm{~mm})$ and on sieve fractions with screen sizes $0.106,0.212,0.5$, and $1 \mathrm{~mm}$, using a dry sieving technique and calculated mean particle size

\begin{tabular}{|c|c|c|c|c|c|c|}
\hline \multirow[b]{2}{*}{ Item } & \multicolumn{6}{|c|}{ Sieve pore size $(\mathrm{mm})$} \\
\hline & $<0.106$ & 0.106 & 0.212 & 0.5 & 1 & Mean $^{1}$ \\
\hline \multicolumn{7}{|c|}{ Grass silage, early cut } \\
\hline $\mathrm{FD}^{2}$ & 5.4 & 27.6 & 46.4 & 17.8 & 2.8 & 0.36 \\
\hline $\mathrm{FBR}^{3}$ & 1.8 & 8.9 & 43.2 & 35.0 & 11.2 & 0.57 \\
\hline $\mathrm{I} 00^{4}$ & 1.4 & 6.1 & 35.4 & 38.1 & 19.0 & 0.69 \\
\hline $\mathrm{I} 24^{5}$ & 5.1 & 15.0 & 36.4 & 36.7 & 6.8 & 0.51 \\
\hline $\mathrm{I} 288^{6}$ & 5.5 & 14.7 & 24.3 & 49.2 & 6.2 & 0.55 \\
\hline \multicolumn{7}{|c|}{ Grass silage, late cut } \\
\hline FD & 3.6 & 16.0 & 38.7 & 35.6 & 6.1 & 0.50 \\
\hline FBR & 2.6 & 9.0 & 32.5 & 41.2 & 14.7 & 0.64 \\
\hline I00 & 1.6 & 4.8 & 25.0 & 52.8 & 15.8 & 0.71 \\
\hline $\mathrm{I} 24$ & 2.1 & 9.9 & 29.8 & 44.6 & 13.6 & 0.64 \\
\hline $\mathrm{I} 288$ & 7.6 & 17.1 & 26.5 & 28.9 & 19.9 & 0.63 \\
\hline \multicolumn{7}{|l|}{ Corn silage } \\
\hline FD & 12.5 & 21.6 & 30.9 & 25.6 & 9.4 & 0.46 \\
\hline FBR & 8.7 & 14.8 & 34.8 & 30.9 & 10.8 & 0.52 \\
\hline I00 & 8.3 & 14.6 & 37.1 & 32.4 & 7.6 & 0.49 \\
\hline $\mathrm{I} 24$ & 4.6 & 11.8 & 38.9 & 33.4 & 11.5 & 0.56 \\
\hline I 288 & 6.8 & 18.6 & 45.5 & 26.8 & 2.4 & 0.41 \\
\hline \multicolumn{7}{|l|}{ Alfalfa silage } \\
\hline FD & 7.3 & 15.5 & 40.0 & 33.3 & 3.9 & 0.45 \\
\hline FBR & 3.3 & 7.8 & 24.8 & 53.0 & 11.1 & 0.64 \\
\hline I00 & 2.7 & 6.7 & 30.9 & 48.7 & 11.0 & 0.63 \\
\hline I24 & 3.6 & 7.4 & 27.3 & 56.2 & 5.5 & 0.58 \\
\hline I 288 & 3.3 & 6.2 & 27.7 & 56.2 & 6.7 & 0.60 \\
\hline \multicolumn{7}{|l|}{$\mathrm{DDG}^{7}$} \\
\hline $\mathrm{FD}$ & 4.8 & 7.5 & 24.5 & 43.8 & 19.4 & 0.70 \\
\hline FBR & 1.8 & 12.6 & 30.5 & 54.2 & 0.9 & 0.52 \\
\hline I00 & 7.1 & 14.8 & 39.0 & 38.3 & 0.8 & 0.44 \\
\hline I 24 & 14.5 & 16.5 & 40.7 & 27.8 & 0.5 & 0.37 \\
\hline I 288 & 8.0 & 11.6 & 43.2 & 37.0 & 0.2 & 0.43 \\
\hline \multicolumn{7}{|c|}{ Rapeseed meal } \\
\hline FD & 3.4 & 10.8 & 36.3 & 41.2 & 8.2 & 0.55 \\
\hline FBR & 4.9 & 10.0 & 38.5 & 46.0 & 0.6 & 0.48 \\
\hline I00 & 4.3 & 10.0 & 43.3 & 42.1 & 0.3 & 0.46 \\
\hline I24 & 5.7 & 10.3 & 39.5 & 43.7 & 0.8 & 0.47 \\
\hline I 288 & 1.4 & 6.0 & 48.4 & 42.4 & 2.0 & 0.50 \\
\hline \multicolumn{7}{|l|}{$P$-value } \\
\hline Feedstuff & 0.064 & 0.094 & 0.14 & 0.017 & 0.060 & 0.15 \\
\hline Treatment & 0.55 & 0.10 & 0.99 & 0.21 & 0.88 & 0.69 \\
\hline \multicolumn{7}{|c|}{$P$-value incubated samples ${ }^{8}$} \\
\hline Feedstuff & 0.087 & 0.16 & 0.003 & 0.037 & 0.005 & 0.002 \\
\hline & 0.56 & 0.42 & 0.95 & 0.87 & 0.41 & 0.23 \\
\hline \multicolumn{7}{|c|}{$P$-value incubated samples ${ }^{8,9}$} \\
\hline Feedstuff & 0.083 & 0.15 & 0.002 & 0.025 & 0.004 & 0.002 \\
\hline Treatment & 0.75 & 0.35 & 0.76 & 0.72 & 0.41 & 0.30 \\
\hline
\end{tabular}

${ }^{1}$ Arithmetic mean (in $\mathrm{mm}$ ).

${ }^{2} \mathrm{FD}=$ dried and ground feedstuffs (1.5-mm screen on a cutter mill).

${ }^{3} \mathrm{FBR}=$ treatment $\mathrm{FD}$, followed by extraction of neutral detergent-soluble (NDS) fraction.

${ }^{4} \mathrm{I} 00=$ treatment $\mathrm{FD}$, followed by machine washing and extraction of NDS fraction.

${ }^{5} \mathrm{I} 24$ = treatment FD, followed by 24 -h in situ rumen incubation and extraction of NDS fraction.

${ }^{6} \mathrm{I} 288$ = treatment FD, followed by 288 -h in situ rumen incubation and extraction of NDS fraction.

${ }^{7}$ Dried distillers grains.

${ }^{8}$ Incubated samples $=$ including treatments I00, I24, and I288.

${ }^{9}$ Treatment analyzed as a continuous variable.

cluded $(P<0.001)$ and when only incubated samples were included with fixed treatment effects $(P=0.006$; Table 4). Across treatments, the highest variations were found for late-cut grass silage $(\mathrm{SD}=0.77 \mathrm{~mm})$ and lowest for DDG (SD $=0.16 \mathrm{~mm})$. Particle length, moreover, differed among treatments $(P=0.049)$ when all treatments were included, with the highest values for I24 samples $(2.31 \pm 1.25 \mathrm{~mm})$ and lowest for I288 
Table 4. Overall particle length (PL), width (PW), and area (PA), and estimated proportion of particle mass (\%) smaller than $144 \times 10^{-6} \mathrm{~mm}^{2}$ and smaller than $0.005 \mathrm{~mm}^{2}$ in area as influenced by feedstuff and treatment ${ }^{1}$

\begin{tabular}{|c|c|c|c|c|c|}
\hline Item & $\begin{array}{l}\mathrm{PL}^{2} \\
(\mathrm{~mm})\end{array}$ & $\begin{array}{l}\mathrm{PW}^{2} \\
(\mathrm{~mm})\end{array}$ & $\begin{array}{l}\mathrm{PA}^{2} \\
\left(\mathrm{~mm}^{2}\right)\end{array}$ & $\begin{array}{c}\text { Particles with area } \\
<144 \times 10^{-6} \mathrm{~mm}^{2} \\
(\%)\end{array}$ & $\begin{array}{l}\text { Particles with area } \\
<0.005 \mathrm{~mm}^{2}(\%)\end{array}$ \\
\hline \multicolumn{6}{|c|}{ Grass silage, early cut } \\
\hline $\mathrm{FD}^{3}$ & 2.93 & 0.37 & 1.01 & 0.004 & 2.64 \\
\hline $\mathrm{FBR}^{4}$ & 3.81 & 0.53 & 2.14 & 0.021 & 1.56 \\
\hline $\mathrm{I} 00^{5}$ & 3.74 & 0.57 & 3.28 & 0.002 & 0.93 \\
\hline $\mathrm{I} 24^{6}$ & 3.27 & 0.40 & 1.39 & 0.012 & 3.00 \\
\hline $\mathrm{I} 288^{7}$ & 2.05 & 0.45 & 0.82 & 0.096 & 10.61 \\
\hline \multicolumn{6}{|c|}{ Grass silage, late cut } \\
\hline FD & 3.03 & 0.47 & 1.55 & 0.0002 & 2.16 \\
\hline FBR & 3.03 & 0.56 & 1.81 & 0.007 & 2.05 \\
\hline I00 & 3.43 & 0.66 & 2.79 & 0.007 & 1.55 \\
\hline I24 & 3.70 & 0.60 & 3.08 & 0.048 & 2.14 \\
\hline I288 & 1.70 & 0.44 & 0.82 & 0.800 & 19.62 \\
\hline \multicolumn{6}{|l|}{ Corn silage } \\
\hline FD & 1.96 & 0.50 & 1.32 & 0.791 & 16.18 \\
\hline FBR & 2.56 & 0.50 & 1.67 & 0.217 & 10.70 \\
\hline $\mathrm{I} 00$ & 1.55 & 0.47 & 1.13 & 0.083 & 14.33 \\
\hline I24 & 3.15 & 0.58 & 2.70 & 0.147 & 5.50 \\
\hline I 288 & 1.59 & 0.42 & 0.62 & 0.006 & 9.41 \\
\hline \multicolumn{6}{|l|}{ Alfalfa silage } \\
\hline FD & 1.64 & 0.44 & 0.89 & 0.117 & 12.49 \\
\hline FBR & 2.33 & 0.63 & 1.71 & 0.302 & 6.21 \\
\hline $\mathrm{I} 00$ & 2.55 & 0.60 & 1.81 & 0.002 & 1.91 \\
\hline I24 & 2.03 & 0.55 & 1.20 & 0.234 & 4.56 \\
\hline I288 & 1.86 & 0.56 & 1.03 & 0.054 & 4.45 \\
\hline \multicolumn{6}{|l|}{$\mathrm{DDG}^{8}$} \\
\hline FD & 1.20 & 0.56 & 0.64 & 0.078 & 7.18 \\
\hline FBR & 0.91 & 0.43 & 0.32 & 0.103 & 8.25 \\
\hline I00 & 0.90 & 0.42 & 0.31 & 0.623 & 11.65 \\
\hline I 24 & 0.77 & 0.37 & 0.20 & 0.150 & 16.22 \\
\hline I 288 & 0.93 & 0.39 & 0.25 & 0.227 & 10.40 \\
\hline \multicolumn{6}{|c|}{ Rapeseed meal } \\
\hline FD & 1.03 & 0.51 & 0.51 & 0.005 & 6.57 \\
\hline FBR & 0.90 & 0.45 & 0.31 & 0.048 & 8.11 \\
\hline I00 & 1.44 & 0.47 & 0.91 & 0.026 & 8.65 \\
\hline I 24 & 0.95 & 0.45 & 0.30 & 0.006 & 4.61 \\
\hline I288 & 1.05 & 0.49 & 0.38 & 0.004 & 2.51 \\
\hline \multicolumn{6}{|l|}{$P$-value } \\
\hline Feedstuff & $<0.001$ & 0.081 & $<0.001$ & 0.51 & 0.13 \\
\hline Treatment & 0.049 & 0.35 & 0.041 & 0.95 & 0.69 \\
\hline \multicolumn{6}{|c|}{$P$-value incubated samples ${ }^{9}$} \\
\hline Feedstuff & 0.006 & 0.053 & 0.061 & 0.46 & 0.38 \\
\hline Treatment & 0.086 & 0.19 & 0.079 & 0.75 & 0.52 \\
\hline \multicolumn{6}{|c|}{$P$-value incubated samples ${ }^{9,10}$} \\
\hline Feedstuff & 0.003 & 0.047 & 0.044 & 0.41 & 0.33 \\
\hline Treatment & 0.024 & 0.11 & 0.022 & 0.46 & 0.25 \\
\hline
\end{tabular}

${ }^{1}$ Values are based on image analysis and given as arithmetic means.

${ }^{2}$ Mean PL, PW, and PA value of the particle mass.

${ }^{3} \mathrm{FD}=$ dried and ground feedstuffs $(1.5-\mathrm{mm}$ screen on a cutter mill).

${ }^{4} \mathrm{FBR}=$ treatment $\mathrm{FD}$, followed by extraction of neutral detergent-soluble (NDS) fraction.

${ }^{5} \mathrm{I} 00=$ treatment $\mathrm{FD}$, followed by machine washing and extraction of NDS fraction.

${ }^{6} \mathrm{I} 24$ = treatment FD, followed by 24 -h in situ rumen incubation and extraction of NDS fraction.

${ }^{7} \mathrm{I} 288$ = treatment FD, followed by 288 -h in situ rumen incubation and extraction of NDS fraction.

${ }^{8}$ Dried distillers grains.

${ }^{9}$ Incubated samples = including treatments I00, I24, and I288.

${ }^{10}$ Treatment analyzed as a continuous variable.

$(1.53 \pm 0.45 \mathrm{~mm})$. When only incubated samples were considered with fixed treatment effects, PL tended to differ among treatments $(P=0.086)$. A linear effect of incubation time on PL $(P=0.024)$ was moreover seen.
Particle length values did not differ between treatments FD and FBR, neither for forages $(P=0.28)$ nor for concentrates $(P=0.33)$. Contrasts showed tendencies for lower PL for I288 than for I00 for forages $(P$ 
$=0.056)$ but not for concentrates $(P=0.40$; data not shown). The highest relative changes in PL within feedstuff when comparing 2 treatments as indicated above were as follows: I24 versus I288: a decrease of $37 \%$ for early-cut grass silage and $54 \%$ for late-cut grass silage; I00 versus I24: an increase of $103 \%$ for corn silage; FD versus FBR: an increase of $42 \%$ for alfalfa silage and a decrease of $24 \%$ for DDG; and FBR versus I00: an increase of $60 \%$ for rapeseed meal.

Particle Width. Particle width tended to differ among feedstuffs $(P=0.081)$, with the highest values for alfalfa silage $(0.55 \pm 0.07 \mathrm{~mm})$ and lowest for DDG $(0.43 \pm 0.08 \mathrm{~mm})$ when all treatments were included. Feedstuff tended to affect PW $(P=0.053)$ when only incubated samples were considered and treatment included as fixed effect. Across treatments, highest variations were found for early- and late-cut grass silage $(\mathrm{SD}=0.09 \mathrm{~mm})$ and lowest for rapeseed meal $(\mathrm{SD}=$ $0.03 \mathrm{~mm}$ ). Treatment did not affect PW systematically when including all treatments or when including only incubated samples (Table 4).

Particle width differed between treatments FD and FBR for forages $(P=0.022)$ and tended to differ for concentrates $(P=0.093)$. Contrasts showed lower PW for I288 than for I00 for forages $(P=0.040)$ but not for concentrates $(P=0.93$; data not shown). The highest relative changes in $\mathrm{PW}$ within feedstuff when comparing 2 treatments as indicated above were as follows: FD versus FBR: an increase of $43 \%$ for early-cut grass silage, an increase of $43 \%$ for alfalfa silage, a decrease of $23 \%$ for DDG, and a decrease of $22 \%$ for rapeseed meal; and I24 versus I288: a decrease of $27 \%$ for late-cut grass silage and a decrease of $28 \%$ for corn silage.

Particle Area. Particle area differed among feedstuffs $(P<0.001)$, with highest values for late-cut grass silage $\left(2.01 \pm 0.92 \mathrm{~mm}^{2}\right)$ and lowest for DDG $(0.34 \pm$ $0.17 \mathrm{~mm}^{2}$ ) when all treatments were considered, and tended to differ among feedstuffs when only incubated samples were considered with fixed treatment effects $(P$ $=0.061$; Table 4 ). Across treatments, highest variations were found for early-cut grass silage $(\mathrm{SD}=1.00 \mathrm{~mm})$ and lowest for DDG (SD $=0.17 \mathrm{~mm})$. Across feedstuffs, PA differed among treatments $(P=0.041)$ when all treatments were considered. Treatment tended to influence PA $(P=0.079)$ when only incubated samples were included with fixed treatment effects. A linear treatment effect on PA was seen $(P=0.022)$ when only incubated samples were considered.

Contrasts showed that PA did not differ between treatments FD and FBR for forages $(P=0.17)$ and concentrates $(P=0.25)$. Particle area was lower for I288 than for I00 for forages $(P<0.001)$ but not for concentrates $(P=0.21$; data not shown) based on orthogonal contrasts, despite numerical lower PA values for I288 than for I00 for forages (PA $=0.8$ for I288 and 2.3 for I00) and concentrates (PA $=0.3$ for I288 and 0.6 for I00). The highest relative changes in PA within feedstuff when comparing 2 treatments as indicated above were as follows: I00 versus I24: a decrease of $58 \%$ for early-cut grass silage and an increase of $139 \%$ for corn silage; I24 versus I288: a decrease of $74 \%$ for latecut grass silage; FD versus FBR: an increase of $92 \%$ for alfalfa silage and an increase of $50 \%$ for DDG; and FBR versus I00: an increase of $194 \%$ for rapeseed meal.

Cumulative distribution functions of PA for treatments I00, I24, and I288 for alfalfa silage and for DDG differed less in the range 0 to $0.05 \mathrm{~mm}^{2}$ than for the other investigated feedstuffs (Figure 1). For early-cut grass silage, the distance between the CDF of PA (in the range 0 to $0.05 \mathrm{~mm}^{2}$ ) was similar between I00 and I24 and between I24 and I288. The largest distances in CDF of PA (in the range 0 to $0.05 \mathrm{~mm}^{2}$ ) were shown for late-cut grass silage between I288 and the other treatments (I00 and I24; Figure 1).

Mass Proportion of Particles Smaller than 144 $\times 10^{-6} \mathrm{~mm}^{2}$. The mass proportion of particles smaller than the Dacron bag pore size area $\left(12 \times 12 \mu \mathrm{m}^{2}=144\right.$ $\times 10^{-6} \mathrm{~mm}^{2}$ ) used for standard iNDF determination did not differ among feedstuffs or treatments (Table 4). The mass proportion of particles smaller than $144 \times$ $10^{-6} \mathrm{~mm}^{2}$ ranged between $0.002 \%$ for early-cut grass silage and alfalfa silage (I00) and $0.8 \%$ for late-cut grass silage (I288) when only incubated samples (I00, I24, and I288) were considered.

Mass Proportion of Particles Smaller than $0.005 \mathrm{~mm}^{2}$. The mass proportion of particles smaller than $0.005 \mathrm{~mm}^{2}$ did not differ among feedstuffs or treatments (Table 4) and ranged between $0.9 \%$ for early-cut grass silage (I00) and $20 \%$ for late-cut grass silage (I288) when only incubated samples (I00, I24, and I288) were considered.

\section{DISCUSSION}

\section{Experimental Design}

The experimental design was chosen to get an overview of particle size alterations and estimate potential particle escape during in situ incubation for a wide range of feedstuffs. Changes in particle size dimensions during NDS extraction and in situ rumen incubation, moreover, were expected to show general trends among feedstuffs. The range of particle size dimensions differed between forage and concentrate samples. Feedstuffs were, therefore, grouped according to type when testing differences between treatments. The 4 forage samples were chosen to represent legumes (alfalfa silage) and grasses. The grasses, moreover, represented C3 (grass 

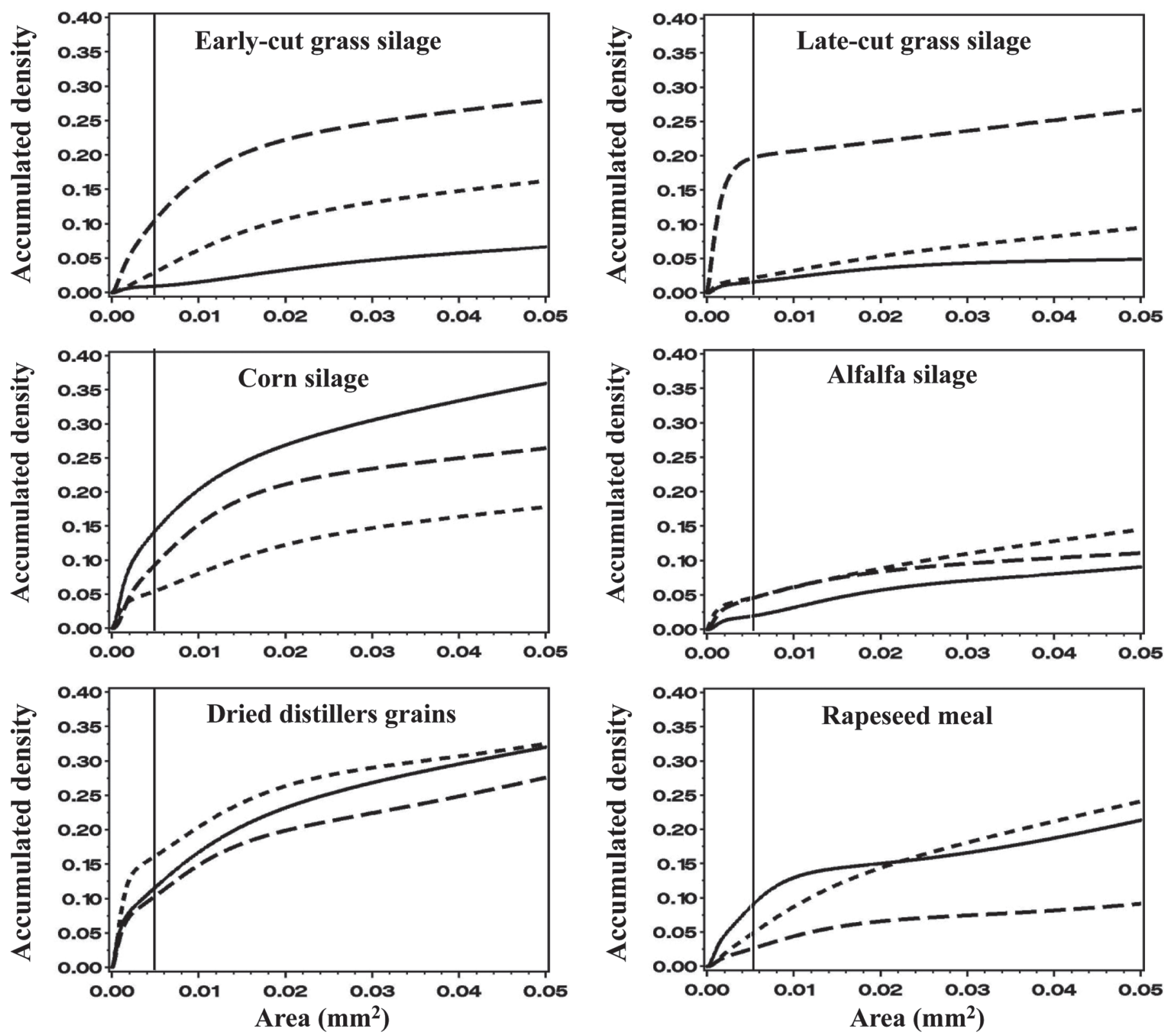

Figure 1. Cumulative distribution functions of particle area in Dacron bag residues after machine washing (- - , 24-h in situ rumen incubation (---), and 288-h in situ rumen incubation (- - ) for forages and concentrates. Vertical line is set at $0.005-\mathrm{mm}^{2}$ particle area.

silages) and C4 (corn silage) photosynthetic pathways and within the $\mathrm{C} 3$ grasses, 2 different harvest times were chosen (early- and late-cut grass silage). Rapeseed meal was chosen as a common by-product used in ruminant nutrition with relatively high fiber concentration and DDG was chosen to represent grain fiber.

\section{Image Analysis and Methodological Considerations}

Particle area is the most reliable image analysis parameter among those presented, because it is the area a particle covers and is directly measured during image analysis. Particle area distribution was, therefore, chosen to evaluate potential particle escape from the Dacron bags. Area reduction, however, did not indicate whether particles were reduced on the outside or empty spaces within the outer particle boundaries increased. Estimated PL and PW values are biased for bended particles because bended particles are truly longer and thinner than the smallest rectangle that surrounds these particles. Forages and concentrates that were ground before further treatment, however, were assumed to 
consist of mainly rectangular, flat particles for which length and width can be measured accurately.

\section{Comparison of Dry Sieving and Image Analysis to Estimate Particle Size}

Dry sieving mainly separates particles according to their diameter, whereas image analysis allows the measurement of particles in 2 dimensions and, therefore, provides information on particle shape (Kennedy, 2005). Image analysis, however, is more extensive in labor than sieving methods. Dry sieving-derived mean particle size values were in the range of $\mathrm{PW}$ values estimated by image analysis, which is in line with Kennedy (2005). Comparison of mean particle size (dry sieving) and PW (image analysis) showed that both methods allocated the maximal mean particle dimension within feedstuff to the same treatment. Within each of the forages and for DDG, moreover, maximal mass proportion of particles in the critical zone for escape was shown for the same treatments when using dry sieving (defined as $<0.106 \mathrm{~mm}$ ) and when using image analysis (defined as $\left.<0.005 \mathrm{~mm}^{2}\right)$.

\section{Particle Size Development in Dacron Bag Residues Analyzed By Image Analysis}

Grinding feedstuffs before in situ rumen incubation is done to improve representative sampling and to attain Dacron bag residues with particle size dimensions that reflect those of particles retained in the rumen in an in vivo situation. Using particle dimensions of washed feces particles for estimation of dimensions in particles escaping the rumen (Jalali et al., 2012a) showed that the screen size of $1.5 \mathrm{~mm}$ resulted in biologically realistic particle dimensions of Dacron bag residues after in situ rumen incubation: PL and PW for I00, I24, and I288 fractions from grass and alfalfa silages (Table 4) were about twice as high as PL $(1.2 \mathrm{~mm})$ and PW $(0.2$ $\mathrm{mm}$ ) of washed feces particles from either sheep fed grass silage (Jalali et al., 2012a), small ruminants fed grass hay or grass seed straw $(\mathrm{PL}=1.1 \mathrm{~mm}$; $\mathrm{PW}=0.2$ $\mathrm{mm}$; Jalali et al., 2012b), or cattle fed alfalfa silage (PL $=1.2 \mathrm{~mm} ; \mathrm{PW}=0.3 \mathrm{~mm}$; Kornfelt et al., 2013).

Changes in particle size between treatments could be interpreted as follows: a decrease in PL, PW, and PA from treatment FD to FBR, FBR to I00, I00 to I24, and I24 to I288 probably indicates that particle size reduction affected particle dimensions more than particle loss from bags, whereas an increase probably indicates that particle loss affected particle dimensions more than a reduction in particle size.

Particle length, PW, and PA as means across treatments were $2.6(\mathrm{PL}), 0.5(\mathrm{PW})$, and $1.6(\mathrm{PA}) \mathrm{mm}$ for forages, which was higher than for concentrates: 1.0 (PL), $0.5(\mathrm{PW})$, and $0.4(\mathrm{PA}) \mathrm{mm}$, which was probably partly caused by the difference in particle dimensions of feedstuffs before grinding. The largest differences among ground feedstuffs were detected for PL and lowest for PW. During the grinding process, particles needed to have a smaller diameter than the screen used for grinding to pass it. After grinding, particles were, therefore, of similar width, whereas their length was more prone to variations.

Orthogonal contrasts between treatments FD and FBR elucidated if particle dimensions of the ground and dried feedstuff represent particle dimensions of the feedstuff s NDF fraction. Orthogonal contrasts showed that NDF particles of ground feed samples (FBR) were numerically larger in PL and PA for forages and smaller for concentrates than ground feed particles (FD). Particle width, however, increased between treatments FD and FBR for forages and tended to decrease for concentrates, indicating that even though PW varied least among particle size dimensions, the effect of NDS extraction was largest for PW. Particle length, PW, and PA of ground forages and concentrates should, therefore, not be used to describe PL, PW, and PA of their fiber fractions. Orthogonal contrasts between machine-washed (I00) and 288-h rumen-incubated feed samples (I288) showed lower PW and PA, and tendencies to lower PL for I288 forages and numerically lower PL, PW, and PA for I288 concentrates. Systematic effects of treatment (I00 vs. I288) in particle dimensions observed for forages in contrast to concentrates is probably caused by larger particle dimensions of forages than concentrates. Effects of initial particle size on particle size reductions have been observed by Ehle et al. (1982) and Nocek and Kohn (1988), who also found larger particle size reductions for large particles than for small particles during digestion and detrition.

Particle size reduction can be caused by mastication during eating and rumination, digestion, and detrition caused by rumen contractions (McLeod and Minson, 1988a). Lower particle size dimensions after in situ rumen incubation (I288) than after machine washing (I00) suggests surface-based particle breakdown, caused by digestion and rumen contractions, as in situ incubated feedstuffs could not be masticated. Moseley and Jones (1984), Murphy and Nicoletti (1984), and Akin (1993) proposed that digestion and detrition only play a minor role in particle size reduction, and allocated the major role to mastication. Other studies found considerable particle size reductions during digestion and detrition (Ehle et al., 1982; Nocek and Kohn, 1988). McLeod and Minson (1988b) showed, based on difference calculations, that digestion and detrition together accounted for $17 \%$ of total particle size reduction of large particles 
( $>1.18 \mathrm{~mm}$ after wet sieving) into small particles. In an in vitro simulation study, McLeod and Minson (1988a) allocated about $14 \%$ of large particle breakdown to digestion and $8 \%$ to detrition. Reductions in PA during rumen incubation of feedstuffs in 12- $\mu$ m Dacron bags suggested that particle escape cannot be excluded.

\section{Particle Escape}

Washing Losses. Machine washing of feed samples led to escape of small particles from Dacron bags with both 12 - and $38-\mu \mathrm{m}$ pore size, indicating that in situ determined NDF degradation parameters and iNDF values must be corrected for initial particle loss of small particles. If washing losses are not taken into account, in situ NDF degradation parameters and iNDF values will be biased to a variable degree depending on feedstuff. The bias will not only affect absolute values but the ranking of feedstuffs could be incorrect as well. Particles that escape from nylon bags during machine washing, however, are assumed to be small particles produced by the grinding process and no additional breakdown of particles during the machine-washing process itself is expected. Particle escape is, therefore, expected to be independent of washing duration. Neutral detergent fiber estimates and degradation parameters, however, are also influenced by particle losses during analysis (Udén, 2006).

Particle Escape During In Situ Rumen Incubation. Particles with an area smaller than the Dacron bag pore size $144 \times 10^{-6} \mathrm{~mm}^{2}$ were detected in small mass proportions $(<1 \%)$. These particles should theoretically have escaped from the bags during either incubation or the following machine washing. Incomplete escape of particles smaller than $144 \times 10^{-6} \mathrm{~mm}^{2}$ supports the assumption that not only particle size but also other particle characteristics such as particle shape and free movement of particles in the bags affect particle entrapment and, thereby, particle escape from the bags (Vanzant et al., 1998).

Mass proportion of particles smaller than $0.005 \mathrm{~mm}^{2}$ was used as an estimate for the mass proportion of particles in the critical zone for escape from $38-\mu \mathrm{m}$ Dacron bags. These particles may have attained the necessary characteristics (e.g., size and shape) to escape through the Dacron bag pores. Mass proportion of particles in the critical zone for escape reached $20 \%$ for treatment I288 in late-cut grass silage; however, the value of 0.005 $\mathrm{mm}^{2}$ was 3.5 times larger than the area corresponding to $38-\mu \mathrm{m}$ Dacron bag pore size $\left(0.0014 \mathrm{~mm}^{2}\right)$. Mass proportion of particles with an area smaller than 0.005 $\mathrm{mm}^{2}$ was highest for early- and late-cut grass silage after 288-h rumen incubation for corn silage and rapeseed meal after machine washing, and for alfalfa silage and DDG after 24-h rumen incubation.
Particles escaping from Dacron bags are those small enough to pass the pores. Particles in the critical zone for escape were observed in variable mass proportions ranging from 1 to $20 \%$, and highest values appeared for different treatments depending on feedstuff, as seen for particles smaller than $144 \times 10^{-6} \mathrm{~mm}^{2}$.

If particle escape only consists of digestible material, the introduced bias will affect the rate of degradation, which will be overestimated, whereas particle escape consisting of only indigestible material will introduce a bias in iNDF parameter estimates, which will be underestimated. If particle escape consists of both digestible and indigestible material, the rate of degradation will be overestimated and iNDF concentration underestimated. As small particles have a higher iNDF:pdNDF ratio than large particles (Kammes and Allen, 2012), and only small particles can escape the bags, particle loss will probably mainly bias iNDF estimates. Large particles are probably degraded at slower rates than small particles (McLeod and Minson, 1969) and, therefore, the escape of small particles high in iNDF will slow the pdNDF degradation rate down. If the slower pdNDF degradation rate of the remaining relatively larger particles in the bags overrides the rate of pdNDF escape contained in small particles, the rate of pdNDF degradation will be underestimated and vice versa.

Particle loss cannot be excluded for feedstuffs with large variations in particle dimensions (large differences among CDF for feedstuffs in Figure 1) among treatments I00, I24, and I288. Late-cut grass silage, corn silage, and early-cut grass silage varied most in PL, PW, and PA between treatments I00 and I24 or between treatments I24 and I288. Combined with a high mass proportion of particles smaller than $0.005 \mathrm{~mm}^{2}$, this imposes a risk for particle loss from the bags during rumen incubation.

As late-cut grass silage showed the highest mass proportion of particles in the critical zone for escape compared with other feedstuffs, a high potential to introduce a bias in in situ estimated NDF degradation parameters is indicated. The highest mass proportion of particles smaller than $0.005 \mathrm{~mm}^{2}$ in late-cut grass silage compared with the other investigated feedstuffs could be due to an extensive breakdown of the brittle latecut grass silage particles during rumen contractions. A linear decrease in PA with increasing rumen incubation time was generally found for the examined feeds, which indicates that the risk for particle loss increases with increasing incubation time.

\section{Differences in Particle Size Alterations Among Feedstuffs}

Corn Silage Versus Grass Silage and Alfalfa Silage. Differences in particle size alterations and 
particle escape between corn silage and grass silage or alfalfa silage could be related to plant origin, as corn silage belongs to tropical C4 grasses, whereas alfalfa silage and grass silage belong to temperate C3 plants. Particle size reduction is slowed down either by slowing physical disruption or by preventing microbial access to cell surfaces. A tight arrangement of parenchyma bundle sheath cells (C4 grasses) with no intercellular spaces forms a substantial barrier to microbial access and bacterial penetration until these structures are physically disrupted (Wilson, 1993). The degradation rate is, therefore, lower in $\mathrm{C} 4$ compared with $\mathrm{C} 3$ plants (Wilson, 1993). Another reason for a lower degradation rate in $\mathrm{C} 4$ compared with $\mathrm{C} 3$ plants is the higher lignin concentration in the cell wall matrix in $\mathrm{C} 4$ plants. Increasing lignin concentration in the cell wall does not only increase the amount of iNDF, as it is indigestible itself (Krämer et al., 2012), but also protects potentially digestible cell wall material against chemical degradation.

The cell form, moreover, influences the resistance of particles against physical breakdown, which is more pronounced for the dovetailed, sinuous-formed epidermal cells in corn silage than for straight-sided (grass silage) and weakly lobed (legume) epidermis cells (Wilson et al., 1989). Differences in particle size reduction between corn silage and other forages can moreover be explained by the very heterogeneous composition of the NDF fractions in corn silage, originating from grain, stover, stem, and leaf material, which differ in lignification, and rate and extent of degradation (Mertens, 2002).

Alfalfa silage as a leguminous species does not have a parallel cell organization as do grass and corn silages with highly organized cells in brick association and parallel arranged stomata (Wilson, 1993). Lacking parallel cell organization in alfalfa silage was assumed to give easier access for rumen microorganisms to degradable cell wall structures, which was reflected in the particle breakdown during the complete rumen incubation period. Alfalfa silage had the lowest PL and PA after drying and grinding among forages. This is in line with Wilson and Kennedy (1996) who found that fragmentation of large legume particles requires less effort than for grasses. A lower NDF concentration, higher lignin, and lower pdNDF concentration in alfalfa silage with a similar rate of pdNDF degradation compared with early-cut grass silage was related to the concentrated lignin location in the xylem (Wilson and Kennedy, 1996).

Forage Versus Concentrate. Dried distillers grains and rapeseed meal showed the lowest average PL, PW, and PA across treatments, as expected, because processed concentrate feedstuffs were small in size before grinding. Rapeseed meal and DDG as by-products had undergone physical (including grinding) and chemical processes before grinding. Smaller particle size of concentrates in treatment FD, which was the basis for all other treatments, probably explains the larger variations in PL and PA among treatments in concentrates than in forages. Dried distillers grains and rapeseed meal, moreover, consisted mainly of seed parts, whereas forages consisted of leaf and stem material and corn silage furthermore of grains and stover. Concentrates had a higher ADL:NDF ratio than forages, suggesting that concentrates were likely to be shed in more and smaller particles than forages during grinding. Different plant tissues, moreover, are likely to differ in ease and pattern of particle breakdown and degradation characteristics (Akin, 1989); thereby causing differences in particle breakdown and degradation characteristics between forages and concentrates. By-product feeds, especially unlignified hulls, brans, and pulp products have a high fiber digestibility, probably because of a high rate of pdNDF degradation (Van Soest, 1994), which was also observed in the present study. High fiber degradation rates in by-products could be due to their generally smaller particle size compared with forage feedstuffs (Van Soest, 1994), as smaller particles have been shown to be degraded at faster rates (McLeod and Minson, 1969). Faster degradation rates of small particles are probably caused by faster microbial entrance into particles and faster attachment to cell walls (Buxton et al., 1996); however, the relation between particle size and surface area available for microbial attachment is questionable, as particles are porous rather than solid (Udén, 1992).

Harvest Time of Grass Silage. During aging, relatively more stem than leaf mass is added, with a higher lignin deposition in stems than in leaves (Jung and Allen, 1995), which leads to an increase in the ADL:NDF ratio. Secondary cell wall thickening and lignification during aging of plants render late-harvested grass silage less digestible than early-cut grass silage, which was reflected in the lower pdNDF fraction in late-cut grass silage than in early-cut grass silage. Higher lignin concentrations both in DM and in NDF in late-cut grass silage compared with early-cut grass silage seemed to protect potentially digestible cell wall material, which was reflected in the slower rate of pdNDF degradation of late-cut grass silage compared with early-cut grass silage. Early-cut grass silage had the highest pdNDF value among investigated feedstuffs and the longest particles as mean across incubated samples, which was probably caused by the lowest ADL:NDF ratio among investigated feedstuffs. Decreasing the lignin content in plant tissues decreases the physical effort needed to break them, but renders particles more elastic, caus- 
ing them to break into longer pieces during grinding (Jung and Allen, 1995), which is in line with Pond et al. (1987), who stated that mature grasses are chewed into smaller particles than immature feeds.

\section{CONCLUSIONS}

Effects of treatment on mean PL, PW, and PA during in situ rumen incubation differed among feedstuffs. Immediate particle loss from 12- and 38- $\mu$ m Dacron bags necessitates a correction of iNDF and NDF degradation parameters. Decreases in PA with prolonged rumen incubation and mass proportion of particles in the critical zone for escape were highest for late-cut grass silage, which imposes a risk for particle loss from the bags during rumen incubation. Particle loss during in situ rumen incubation should be investigated by direct analysis of the fraction that escapes from the bags to conclude whether modifications of the in situ procedure to prevent particle loss are needed.

\section{ACKNOWLEDGMENTS}

The authors gratefully acknowledge T. N. Jakobsen (Department of Animal Science, Aarhus University, Tjele, Denmark) for his skillful practical assistance. The project was funded by the Commission of the European Communities, FP7, KBB-2007-1, and "Mælkeafgiftsfonden" through the project "Development of methods for estimation of iNDF in feedstuffs."

\section{REFERENCES}

Åkerlind, M., M. R. Weisbjerg, T. Eriksson, R. Tøgersen, P. Udén, B. L. Ólafsson, O. M. Harstad, and H. Volden. 2011. Feed analyses and digestion methods. Pages 41-54 in NorFor-The Nordic Feed Evaluation System. H. Volden, ed. Wageningen Academic Publishers, Wageningen, the Netherlands.

Akin, D. E. 1989. Histological and physical factors affecting digestibility of forages. Agron. J. 81:17-25.

Akin, D. E. 1993. Perspectives of cell wall biodegradation-Session synopsis. Pages 73-82 in Forage Cell Wall Structure and Digestibility. H. G. Jung, D. R. Buxton, R. D. Hatfield, and J. Ralph, ed. Am. Soc. Agron. Inc., Crop Sci. Soc. Am. Inc., Soil Sci. Soc. Am. Inc., Madison, WI.

Buxton, D. R., D. R. Mertens, and D. S. Fisher. 1996. Forage quality and ruminant utilization. Pages 229-266 in Cool-Season Forage Grasses. L. E. Moser, D. R. Buxton, and M. Darwin, ed. Am. Soc. Agron. Inc., Crop Sci. Soc. Am. Inc., Soil Sci. Soc. Am. Inc., Madison, WI.

Crawley, M. J. 2007. The R Book. John Wiley \& Sons Ltd., West Sussex, UK. Accessed Apr. 29, 2013. http://ia700206.us.archive. org/13/items/TheRBook/The_R_Book-Crawley.pdf.

Ehle, F. R., M. R. Murphy, and J. H. Clark. 1982. In situ particle-size reduction and the effect of particle-size on degradation of crude protein and dry-matter in the rumen of dairy steers. J. Dairy Sci. 65:963-971.

Hansen, B. 1989. Determination of nitrogen as elementary N, an alternative to Kjeldahl. Acta Agric. Scand. 39:113-118.
Huhtanen, P., S. Ahvenjärvi, M. R. Weisbjerg, and P. Nørgaard. 2006. Digestion and passage of fibre in ruminants. Pages 87-135 in Ruminant Physiology: Digestion, Metabolism and Impact of Nutrition on Gene Expression, Immunology and Stress. K. Sejrsen, T. Hvelplund, and M. O. Nielsen, ed. Wageningen Press, Wageningen, the Netherlands.

ISO (International Organization for Standardization). 2008. Animal feeding stuffs - Determination of acid detergent fibre (ADF) and acid detergent lignin (ADL) contents. ISO 13906:2008. ISO, Geneva, Switzerland.

Jalali, A. R., P. Nørgaard, M. R. Weisbjerg, and E. Nadeau. 2012a. Effect of stage of maturity of grass at harvest on intake, chewing activity and distribution of particle size in faeces from pregnant ewes. Animal 6:1774-1783.

Jalali, A. R., P. Nørgaard, M. R. Weisbjerg, and M. O. Nielsen. 2012b. Effect of forage quality on intake, chewing activity, faecal particle size distribution, and digestibility of neutral detergent fibre in sheep, goats, and llamas. Small Rumin. Res. 103:143-151.

Jung, H. G., and M. S. Allen. 1995. Characteristics of plant cell walls affecting intake and digestibility of forages by ruminants. J. Anim. Sci. 73:2774-2790.

Kammes, K. L., and M. S. Allen. 2012. Rates of particle size reduction and passage are faster for legume compared with cool-season grass, resulting in lower rumen fill and less effective fiber. J. Dairy Sci. 95:3288-3297.

Kennedy, P. M. 2005. Particle dynamics. Pages 123-156 in Quantitative Aspects of Ruminant Digestion. J. Dijkstra, J. M. Forbes, and J. France, ed. CABI Publishing, Cambridge, MA.

Kornfelt, L. F., M. R. Weisbjerg, and P. Nørgaard. 2013. Effect of harvest time and physical form of alfalfa silage on chewing time and particle size distribution in boli, rumen content and faeces. Animal 7:232-244.

Krämer, M., M. R. Weisbjerg, P. Lund, C. S. Jensen, and M. G. Pedersen. 2012. Estimation of indigestible NDF in forages and concentrates from cell wall composition. Anim. Feed Sci. Technol. $177: 40-51$

McLeod, M. N., and D. J. Minson. 1969. Sources of variation in the in vitro digestibility of tropical grasses. J. Br. Grassl. Soc. 24:244249.

McLeod, M. N., and D. J. Minson. 1988a. Breakdown of large particles in forage by simulated digestion and detrition. J. Anim. Sci. $66: 1000-1004$.

McLeod, M. N., and D. J. Minson. 1988b. Large particle breakdown by cattle eating ryegrass and alfalfa. J. Anim. Sci. 66:992-999.

Mertens, D. R. 2002. Fiber: Measuring, modeling and feeding. Pages 1-18 in Proc. Cornell Nutrition Conference for Feed Manufacturers. Cornell Univ., Ithaca, NY.

Mertens, D. R. 2002. Gravimetric determination of amylase-treated neutral detergent fiber in feeds with refluxing in beakers or crucibles: Collaborative study. J. AOAC Int. 85:1217-1240.

Moseley, G., and J. R. Jones. 1984. The physical digestion of perennial ryegrass (Lolium perenne) and white clover (Trifolium repens) in the foregut of sheep. Br. J. Nutr. 52:381-390.

Murphy, M. R., and J. M. Nicoletti. 1984. Potential reduction of forage and rumen digesta particle-size by microbial action. J. Dairy Sci. $67: 1221-1226$.

Nocek, J. E., and R. A. Kohn. 1988. In situ particle-size reduction of alfalfa and timothy hay as influenced by form and particle-size. J. Dairy Sci. 71:932-945.

Nørgaard, P. 2006. Use of image analysis for measuring particle size in feed, digesta and faeces. Pages 579-585 in Ruminant Physiology: Digestion, Metabolism and Impact of Nutrition on Gene Expression, Immunology and Stress. K. Sejrsen, T. Hvelplund, and M. O. Nielsen, ed. Wageningen Academic Publishers, Wageningen, the Netherlands.

Nørgaard, P., S. Husted, and H. Ranvig. 2004. Effect of supplementation with whole wheat or whole oat grains on the dimensions of faeces particles from lambs. J. Anim. Feed Sci. 13(Suppl. 1): $175-178$.

NRC. 2001. Nutrient Requirements of Dairy Cattle. 7th rev. ed. Natl. Acad. Press, Washington, DC. 
Pond, K. R., W. C. Ellis, C. E. Lascano, and D. E. Akin. 1987. Fragmentation and flow of grazed coastal bermudagrass through the digestive-tract of cattle. J. Anim. Sci. 65:609-618.

SAS Institute. 2000. Statistical Analysis System. User's Guide. SAS Institute Inc., Cary, NC.

Udén, P. 1992. The influence of leaf and stem particle size in vitro and of sample size in sacco on neutral detergent fibre fermentation kinetics. Anim. Feed Sci. Technol. 37:85-97.

Udén, P. 2006. Recovery of insoluble fibre fractions by filtration and centrifugation. Anim. Feed Sci. Technol. 129:316-328.

Van Soest, P. J. 1994. Nutritional Ecology of the Ruminant. 2nd ed Comstock Publishing Associates, Cornell University Press, Ithaca, NY.

Van Soest, P. J., and R. H. Wine. 1967. Use of detergents in analysis of fibrous feeds. 4. Determination of plant cell-wall constituents. J. Assoc. Off. Anal. Chem. 50:50-55.

Vanzant, E. S., R. C. Cochran, and E. C. Titgemeyer. 1998. Standardization of in situ techniques for ruminant feedstuff evaluation. J. Anim. Sci. 76:2717-2729.
Volden, H. 2011. NorFor-The Nordic Feed Evaluation System. EAAP Publication, Wageningen Academic Publishers, Wageningen, the Netherlands.

Wilson, J. R. 1993. Organization of forage plant tissue. Pages 1-32 in Forage Cell Wall Structure and Digestibility. H. G. Jung, D. R. Buxton, R. D. Hatfield, and J. Ralph, ed. Am. Soc. Agron. Inc., Crop Sci. Soc. Am. Inc., Soil Sci. Soc. Am. Inc., Madison, WI.

Wilson, J. R., and P. M. Kennedy. 1996. Plant and animal constraints to voluntary feed intake associated with fibre characteristics and particle breakdown and passage in ruminants. Aust. J. Agric. Res. 47:199-225.

Wilson, J. R., M. N. McLeod, and D. J. Minson. 1989. Particle size reduction of the leaves of a tropical and a temperate grass by cattle. Grass Forage Sci. 44:55-63. 